\title{
Concerns and Intentions among Young Migrants in the Shoe-shine Business in the Cape Coast Metropolis, Ghana
}

\author{
Augustine Tanle \\ University of Cape Coast, Cape Coast \\ Department of Population and Health \\ atanle@ucc.edu.gh \\ DOI//http://dx.doi.org/10.4314/gjds.v15i1.3
}

\begin{abstract}
In sub-Saharan Africa, studies on young people engaged in the shoe-shine business are scanty and also their future intentions in the business are not known. This paper examines the concerns and intentions among young migrants involved in the shoe-shine business in the Cape Coast Metropolis. Through snowball sampling, 191 responded to a questionnaire while 15 others participated in in-depth interviews. The data were analysed using logistic regression and content analysis. The main concerns were injuries, physical stress, exposure to malaria and thieves. Consequently, some of them intend to quit the job in future due to physical stress, aging, declining earnings, inability to combine the job with farming at their places of origin and the precarious nature of the job. The study concluded that the shoe-shine business could be described as a stepping stone to more lucrative and stable jobs due to the challenges involved. There is the need for the National Board for Small-Scale Industries and other relevant state institutions to build the capacities of young people who have already created their own jobs in the informal sector such as the shoe-shine boys to enable them sustain their businesses.
\end{abstract}

Keywords: Migrants, Shoe-shine Business, Intentions to Remain or Quit, Cape Coast Metropolis, Ghana

\section{Introduction}

In sub-Saharan Africa, studies on the shoe-shine business indicate that it began in the colonial era where people with such skills were engaged by some African elites and civil servants who probably did not have house servants like the expatriates to polish their shoes nor enough time or skills to polish their own shoes (Elkan, Ryan, and Mukui, 1982). The shoe-shine business has no specific definition, it is mostly 
carried out by young males who often move about or stay at one particular place to polish and/or mend shoes for a living.

In Ghana, the shoe-shine business is one of the informal sector businesses that some young people engage in in most towns and cities but it has not attracted much research compared to other informal sector businesses such as hair dressing, tailoring, mechanic and others (Kwankye, Anarfi, Tagoe, and Castaldo, 2007; Owusu, Blankson, and Abane, 2011; Ghana Social Marketing Foundation, 2003). The study adopts the definition of young people or youth proposed by the National Youth Policy as those aged between 15-35 years (UNFPA, 2011; GSS, 2012). They account for a third (33.8\%) of the population but about half of them are unemployed (GSS, 2012). The rationale for the study therefore is to update and expand the limited literature in Ghana on the shoe-shine business. The study focuses on the mobile shoe-shiners who are young migrants who constitute the majority in the business in the Cape Coast Metropolis. The study is guided by the following research questions: 1) What are the background characteristics of the shoe-shine operators? 2) What are the concerns of the shoe-shine operators? and 3) What are their future intentions in the business? The paper which is divided into six sections covers the introduction, empirical and theoretical literature, the study area, data and methods, results and discussion, conclusions and recommendations.

\section{Empirical Literature}

In Ghana, a shoe-shine boy, as they are commonly referred to, is usually a young male aged below 30 who moves about or stays at one particular place and polishes and/or mends shoes for a living. The job is gender-based, especially in Ghana and this could be attributed to the fact that, culturally, males are expected to be more adventurous than females (Author, 2010; Author, 2012). A shoe-shine boy often carries a tool box which is usually a wooden box containing all the necessary accoutrements which include tins of polish of different colours and a set of brushes for polishing shoes; threads, needles, glue, nails, a small hammer and other tools for mending shoes. They often move from one place to the other advertising their trade/presence by occasionally knocking on the wooden box to attract customers. They usually work every day in the week unless for very compelling reasons. A typical day's activity of a shoe-shine boy begins at about 6:00 a.m. through the afternoon (but some do take a brief rest in the afternoon due to tiredness and/or the intensity of the scorching sun) to about 6:00 p.m. depending on the availability of customers (Personal communication, 2016). In this paper, the term 'shoe-shine boys' will be used interchangeably with shoe-shine operators or shoe-shiners. 
In sub-Saharan Africa, literature on the shoe-shine business is very scanty. The only substantive paper found on the shoe-shine business in the literature review was an article published by Elkan et al.(1982) in Nairobi, Kenya. The authors among other things documented the following information about the shoe-shine business in Nairobi: That the shoe-shine business started in the Nairobi town, particularly in the central streets of Kenyatta Avenue, Moi Avenue and Tom Mboya Street, and the main customers were the African elites and civil servants engaged in white-collar jobs. That the City Council Authorities initially employed all sorts of measures including compulsory licensing and occasional police swoop at places where the shoe-shiners operate in order to keep them away from the central business districts where they were considered to be nuisance (Elkan et al., 1982). The shoe-shiners, according to the paper, were aged between 17 and 34 years and were mostly of the Kikuyu ethnic group who dominated the business through the social networks established over the years. The authors further intimated that the shoe-shine business was dwindling because of increase in the number of operators which result in low earnings.

In another study in Kenya titled: "Shoe-shine entrepreneurs' social responsibility practices on loyalty", Matelong, Sergon, Tuwei, and Cheptumo (2013) found out that the shoe shine enterprises still need to improve on their social responsibility practices in terms of reasonable pricing, equal treatment to all customers and proper waste disposal and among other things.

From a UNICEF report on children working in the streets of Ethiopia which included the shoe-shiners, it was observed that the children experience the rough weather in the course of their work such as extremely cold mornings and evenings while the heat during the afternoons and dry season were equally unbearable. The report further indicated that their concerns were the feeling of insecurity emanating from not making sufficient money and having bleak futures because of no or low formal education (UNICEF, 2000). From the report, the shoe-shiners who were all males, combine their work with washing and watching cars at the pavements while those who work around market areas carry goods in addition to shoe shinning.

Apart from sub-Saharan Africa, it has also been observed in Hong Kong that the shoe-shine business started in the late $19^{\text {th }}$ century, and the white-collar workers in the financial district were the main customers (Feed Magazine, 2015). That since the early 1970s, the Hong Kong Urban Council refused to issue licenses to the shoeshiners as the industry was dwindling with time. The report further noted that in Hong Kong most of the shoe-shiners were 60 years or above and some were unable to work due to health problems but they continued to serve the people because they 
still had to make ends meet. Finally, that due to the low monthly income, young people are reluctant to join the shoe-shine business (Feed Magazine, 2015).

The shoe-shine business is one of the informal sector businesses that is common in most cities and urban areas in sub-Saharan Africa. The term informal sector or economy has several different definitions but this paper adopts the definition by Khotkina (2007) as any legal income generating activity resulting in the production of goods and services by workers who are outside the organized workforce which may or may not include any violation of legal laws. In sub-Saharan Africa, the informal economy is the main employer of most young migrants who are either employees or have created their own jobs through various social networks. In Burkina Faso, for example, it has been observed that among young migrants from Bisa, the oldest or seniors normally lead the young first time migrants to Ouagadougou where they initiate them into the shoe-shine business and later assist them to find more permanent employment in small food kiosks, restaurants and bars after they (new arrivals) had become familiar with the urban environment (Thorsen, 2009). This is consistent with the fact that social networks facilitate migration to and employment in urban centres (Kwankye et al., 2007; Author and Awusabo-Asare, 2007; Author, 2010).

In Ghana, a number of studies have reported on the growing youth enterprises or entrepreneurship in the informal economy partly because of the ease with which one could establish his or her own business (Abebe, 2007; Porter, Hampshire, Abane, Author, Esia-Donkoh, Amoako-Sakyi, Agblorti, and Owusu, 2011; Thilde, Katherine, Gough, Yankson, Owusu and Osei, 2015). For instance, studies showed that in both Kumasi and Accra, some female migrants are engaged in the kaya yei business (female head porters who carry all kinds of loads or goods for some fees) and street vending or petty trading while some of their male counterparts are technicians or mechanics, petty traders or truck pushers (porters transporting goods on small carts) (Kwankye, Anarfi, Tagoe, and Castaldo, 2007; Author and Awusabo-Asare, 2007; Awumbila and Ardayfio-Schandorf, 2008; Author, 2010).

\section{Theoretical Literature on Future Intentions in a Job}

From the literature, intentions to remain or quit a job, whether in the formal or informal sector, can be influenced by background characteristics such as age, marital status, level of education, income and other factors which include stress and job satisfaction (Werbel and Bedeian, 1989; Ongori, 2007; Böckerman and Ilmakunnas, 2007; Masroor and Fakir, 2010; Mxenge, Dywili and Bazana, 2014). As people grow older, a number of factors could influence their decisions in the 
job that they do. For instance, their interests and needs could change with time and this may result in some quitting a job or taking early retirement or looking for lighter jobs if the current job demands more physical energy but this will depend on the availability of the desired alternative jobs. Marital status could also influence the intention to remain or quit a job. When one spouse wants to join the other elsewhere or when one spouse is divorced he/she might want to quit the job and begin a new life elsewhere (Mxenge et al., 2014). It has also been noted that an employee's educational advancement could contribute to his/her intention to remain or quit a job, particularly where it is perceived that the compensation for staying with current employment differs from that of another employment, the employee might consider leaving for the better one (Jonathan, Thibeli and Darroux, 2013). Income or the general compensation package could also influence the intention to remain or quit a job. Whether one will remain or quit a job depends to a large extent on how he/she perceives the income or compensation earned at the current job and also compensation packages in other organizations in relation to the workload (Masroor and Fakir, 2010).

Besides the background characteristics of an employee, stress is one of the other factors identified in the literature that could influence the intention to remain or quit a job. The demands or workload involved in a job might lead to increased stress, dissatisfaction in the job and intention to quit the job (Mxenge et al., 2014). Job satisfaction is another factor that could influence the intention to remain or quit a job. Job satisfaction is defined by Locke (1976) as the 'worker's appraisal of the degree to which the work environment fulfils the individual's need'. It can be measured in terms of both extrinsic and intrinsic values. The former comprises tangible issues such as wages, benefits and bonuses whilst social status, recognition, personal and professional development opportunities and others constitute the intrinsic values (Cowin, 2002). Thus, a shoe-shiner may decide to remain or quit the business due to some of these factors

\section{Study Area}

The Cape Coast Metropolis is the capital of the Central Region of Ghana and the first national capital of the Gold Coast, now Ghana. It is bounded on the South by the Gulf of Guinea, West by the Komenda-Edina-Eguafo-Abrem Municipality, East by the Abura-Asebu - Kwamankese District and North by the Twifu Hemang Lower Denkyira District (Fig. 1). The Metropolis which covers an area of about 122 square kilometres has an estimated population of 169,894 , comprising $48.7 \%$ males and $51.5 \%$ females (GSS, 2012). The Cape Coast Metropolis is endowed with historical, traditional and cultural resources which have made the Metropolis the 
tourism destination of the country. As a former seat of the colonial government, the population of the then Cape Coast District comprised expatriates, Africa elites and civil servants who were customers to the shoe-shiners, encouraged the growth of the business in the town.

The amenities in the Metropolis include the main kutokraba market and some satellite markets, banking, hotels and health facilities. Formal education is the main industry of the town which has some of the best pre-tertiary educational institutions in the country. The Metropolis is more suitable for the shoe-shine business because it has large proportion of public and civil servants and students who constitute over 60.0 per cent of the total clients who patronize the services of the shoe-shine operators. Personal interactions with the shoe-shine boys indicate that almost all of them hail from rural communities within the Central Region, especially from the Assin communities.

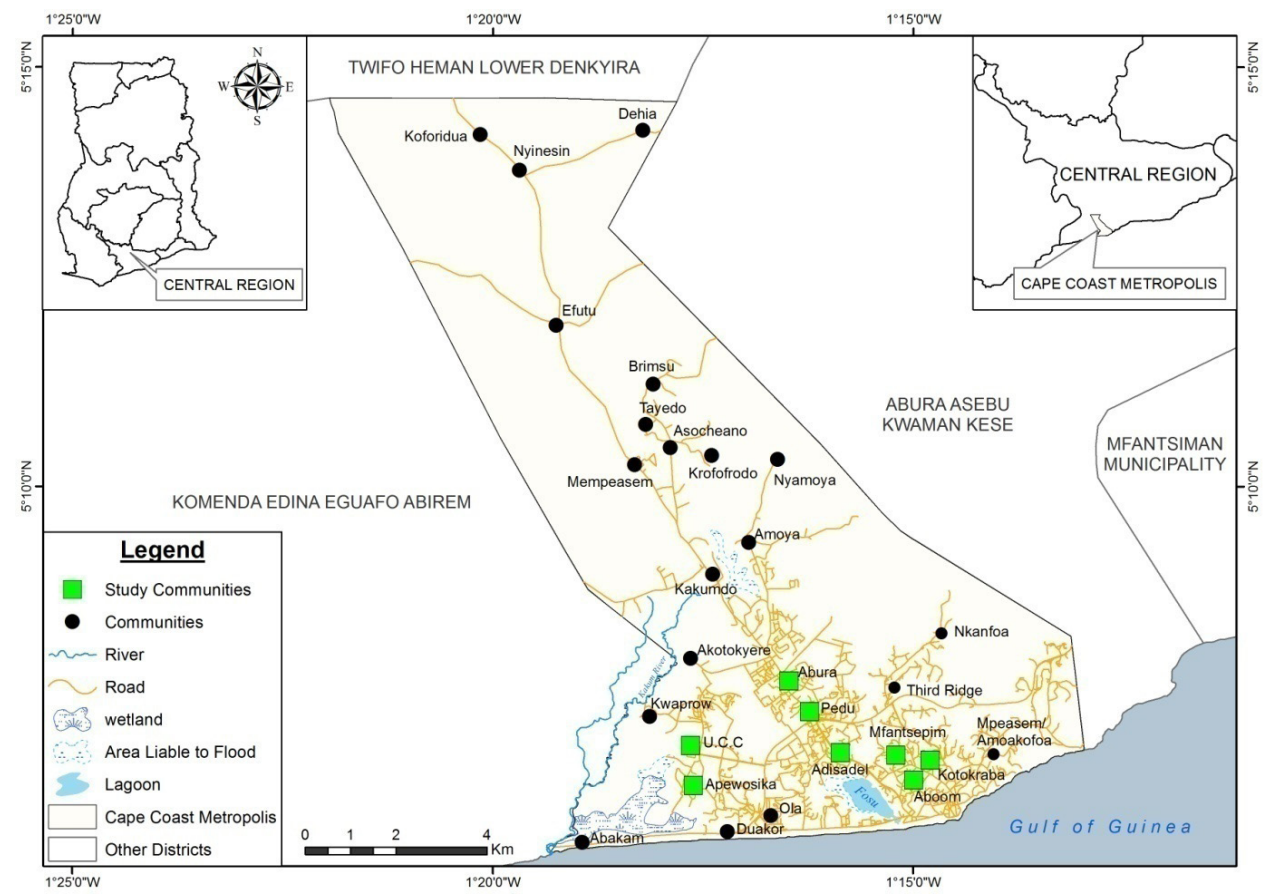

Fig.1: Map of the cape coast metropolis showing the study sites

Source: Remote Sensing and Cartographic Unit of the Department of Geography and Regional Planning, University of Cape Coast, Cape Coast. 


\section{Data and Methods}

A sample size could not be determined because the total number of the shoeshine boys in the Cape Coast Metropolis was unknown. The snowball sampling procedure was therefore adopted. After the first shoe-shine boy was contacted and interviewed, he was asked to provide information about where his colleagues could be found. This procedure was followed until no shoe-shine boy was found who had not been covered in the study. In all, 191 were interviewed using a survey questionnaire while 15 others were interviewed using an in-depth interview guide. The field assistants were final year students from the Department of Population and Health, University of Cape Coast. They had a day's training on the instruments and pre-tested the instruments at the Komenda-Edina-Eguafo - Abrem Municipality before the actual data collection. The instruments covered questions such as background characteristics, motives and frequency of movements to the Cape Coast Metropolis, nature of work, health-seeking behaviour, benefits and experiences in the business, effects of their migration on households at places of origin and future intentions in the business.

The Statistical Package for Service Solution (SPSS) version 21 was used to input the quantitative data while the interviews which were tape-recorded were transcribed. Both descriptive and inferential statistical tools were used to analyse the quantitative data. The logit regression model was used for the inferential statistics since the dependent variable for intentions to remain or quit was a binary outcome. The qualitative data were analysed using content analysis based on common themes and direct quotes from respondents.

\section{Results and Discussion}

\section{Background Characteristics of Respondents}

This section focuses on research question one on background characteristics of the respondents. The results in Table 1 showed that the respondents were mostly males, aged between 20 and 29 years and were single, which is consistent with the findings of the study conducted in Nairobi by Elkan et al. (1982). The shoe-shiners are males because culturally males are expected to be more adventurous than their female counterparts (Author, 2010; Author, 2012). More than three-quarters were basic school graduates (Primary and Middle/Junior High School (JHS) and most of them belonged to the Akan ethnic group (80.2\%). This is consistent with the 2010 Population and Housing Census report which indicated that Akans constituted the largest ethnic group in Ghana (GSS, 2012). Majority of them (75.0 \%) earned less 
than GHC 100.00 (USD\$25.20) a month prior to migration but after migration about seven out of ten earned more than GHC 400.00. (USD\$102.00) per month (i.e. USD\$ 1.00 to GHC 3.97 as at September, 2016).

Table 1: Socio-demographic characteristics of respondents $(N=191)$

\begin{tabular}{|c|c|c|}
\hline Characteristics & Frequency & Percentage \\
\hline \multicolumn{3}{|l|}{ Age } \\
\hline $10-19$ & 8 & 4.2 \\
\hline $20-29$ & 138 & 72.3 \\
\hline 30-39 & 45 & 23.6 \\
\hline \multicolumn{3}{|l|}{ Marital status } \\
\hline Single & 114 & 59.7 \\
\hline Married & 52 & 27.2 \\
\hline Separated & 10 & 5.2 \\
\hline Divorced & 15 & 7.9 \\
\hline \multicolumn{3}{|c|}{ Level of education } \\
\hline None & 27 & 14.1 \\
\hline Primary & 55 & 28.8 \\
\hline Middle/JSS & 91 & 47.6 \\
\hline Secondary & 18 & 9.4 \\
\hline \multicolumn{3}{|l|}{ Ethnicity } \\
\hline Mole Dagbani & 18 & 9.4 \\
\hline Akan & 153 & 80.2 \\
\hline Ewe & 14 & $7 \cdot 3$ \\
\hline Ga/Adangbe & 6 & 3.1 \\
\hline \multicolumn{3}{|c|}{ Income per month prior to migration } \\
\hline None & 8 & 4.2 \\
\hline$<50$ & 75 & $39 \cdot 3$ \\
\hline $50-100$ & 60 & 31.4 \\
\hline $101-200$ & 36 & 18.8 \\
\hline$>201$ & 12 & 6.3 \\
\hline \multicolumn{3}{|c|}{ Income per month after migration } \\
\hline$<200$ & 19 & 9.9 \\
\hline 201-300 & 22 & 11.5 \\
\hline $301-400$ & 21 & 11.0 \\
\hline $401-500$ & 51 & 26.7 \\
\hline$>500$ & 78 & 40.8 \\
\hline Total & 191 & 100.0 \\
\hline
\end{tabular}

Source: Fieldwork, September, 2016. 


\section{Shoe-shine Boys' Concerns about Their Job}

From the second research question, the quantitative results showed four main concerns reported by the shoe-shine boys which bordered on their places of origin and destination (Table 2). These were health (36.5\%), effects of being absent from home (34.7\%), economic (17.8\%), and accommodation challenges at destination (11.0\%). Specifically, it was observed that diseases (64.2\%) at the destination, inability to remit home (6o.8\%), and the limited size of their sleeping rooms were major worries to the respondents. They also lamented that their absence from their places of origin had affected output in farming (49.3\%) and security of their households (5.5\%).

Table 2: Shoe-shine boys' concerns about their Job

\begin{tabular}{|l|l|l|l|}
\hline Concerns & N & Sub (\%) & Total (\%) \\
\hline Economic factors & 102 & & 17.8 \\
\hline Job not lucrative & 40 & 39.2 & \\
\hline Inability to remit home & 62 & 60.8 & \\
\hline Accommodation challenges & 63 & & 11.0 \\
\hline Rooms are small in size & 37 & 58.8 & \\
\hline Rooms are too expensive & 26 & 41.2 & \\
\hline Health & 209 & & 36.5 \\
\hline Diseases (eg. Malaria, Cholera) & 134 & 64.2 & \\
\hline Job is stressful & 75 & 35.8 & \\
\hline Effect back home & 199 & & 34.7 \\
\hline My absence has affected security at home & 11 & 5.5 & \\
\hline My absence has affected output in farming & 98 & 49.3 & \\
\hline My absence has affected household chores & 90 & 45.2 & \\
\hline
\end{tabular}

Source: Fieldwork, September, 2016.

\section{Influence of Shoe-shine Boys' Concerns on their Intentions to Remain or Quit the Job}

The study further explored the possible influence of the concerns expressed by the respondents on their intentions to remain or quit the job. The estimated logit model showed that about 29 per cent of the intention to quit was explained by the concerns raised (Table 3). Though the variables used were not able to explain most of the variance of the regressand, they were highly significant at 0.01 levels. The $P$ value of the Omnibus Tests of Model Coefficient is less than 0.05 which suggests that the model is a reliable predictor (Pallant, 2005; Adongo, Anuga and Dayour, 
2015). This was further confirmed by the Hosmer and Lemeshow Test score $\left(x^{2}\right.$ $=3.421 ; \mathrm{P}=0.2531)$. Three out of the nine variables were found to be significant to the model. Stress emerged as the greatest predictor. Those who considered the job stressful were by a factor of 7.855 times more likely to quit. Another factor that was more likely to influence respondents' intentions to remain or quit was the prospects offered by the job (odds $=2.157$ ). This implies that the less lucrative a job is, the likelihood of quitting is $\mathbf{2 . 1 5 7}$ which is consistent with the literature (Masroor and Fakir, 2010). Respondents who also felt that their absence had affected their farm output at their places of origin were about 5.435 times likely to leave the job.

Table 3: Influence of shoe-shine boys' concerns on their intentions to quit the job

\begin{tabular}{|l|l|l|l|}
\hline Concerns & Odds ratio & $\mathrm{Z}$ & P value \\
\hline Economic factors & & & \\
\hline Job not lucrative & 2.157 & 2.20 & $0.028^{*}$ \\
\hline Inability to remit home & 0.693 & 0.41 & 0.679 \\
\hline Accommodation challenges & & & \\
\hline Rooms are small in size & 0.760 & -0.23 & 0.819 \\
\hline Rooms are too expensive & 1.117 & 0.08 & 0.933 \\
\hline Health & & & \\
\hline Diseases (eg. Malaria, Cholera) & 0.626 & 0.33 & 0.741 \\
\hline Job is stressful & 7.855 & 1.97 & $0.049^{*}$ \\
\hline Effects back home & & & \\
\hline My absence has affected security at home & 0.798 & 0.23 & 0.820 \\
\hline My absence has affected output in farming & 5.435 & 2.88 & $0.000^{* *}$ \\
\hline My absence has affected household chores & 0.438 & -0.83 & 0.409 \\
\hline
\end{tabular}

Pseudo $\mathrm{R}^{2}=0.286 ; \mathrm{P}=0.000 ; \mathrm{P} \leq 0.05^{*} ; \mathrm{P}<0.01^{* *}$

Source: Fieldwork, September, 2016.

The results from the qualitative data provided more detailed information on their concerns which are the risks involved in the business and the implications of being absent from their home villages due to the business. The risks, according to some of them, included injuries, poor accommodation, physical stress and exposure to thieves.

Work place injuries do occur occasionally among workers in both the formal and informal sectors. However, in most developing countries, policies on occupational health and safety are mostly limited to only the formal sector. In Ghana, for example, although about nine out of ten people are employed in the private informal sector, there are no legal provisions which specifically address 
occupational health and safety in that sector (Ghartey and Dorkenoo, 2002; Adei and Kuufaa, 2007; Author, Ilechie, Awusabo-Asare, Ovenseri, and Anderson, 2011). The shoe-shine business is one of such businesses which is not covered by any occupational health and safety policies.

The injuries according to them were mostly caused by the needles they used as stated in the following excerpts: I pierced my thigh with a needle about three years ago. It got so stuck and when l tried to pull it out some of my flesh tried coming out. My thigh was swollen and it caused me so much pains. My friend carried me to the hospital in the night since it was late. The needle was pulled out the following day. I suffered for two months without working (28 years, Single, JHS).

In 2006, laccidentally pricked my thumb together with the shoe so l went to a nearby clinic where they cut the shoe before l could take my finger out. I had to stay away from work for two weeks. After the first visit to the clinic, l did not go there again because l did not have money to pay for the expenses and l also didn't have health insurance card, so l depended on drugstores until l became okay (35 years, Married, JHS).

From the findings, some of the shoe-shiners who sustain injuries at their work places have to bear the cost by themselves since some of them have not registered with the National Health Insurance Scheme which means that they cannot access healthcare services from the hospitals whenever they sustain injuries in the course of their work. This explains why some of them resort to drugstores and selfmedication whenever they are injured.

Poor accommodation was also mentioned as one of their concerns. Almost all of them reported that they sleep on verandas in front of stores while others live in kiosks. Owing to this, they are exposed to the vagaries of the weather in both the rainy and dry seasons, especially mosquito bites which predispose them to malaria. According to some of them, malaria is the major health problem that they face as a result of poor accommodation which is consistent with the fact that malaria is the leading cause of morbidity and mortality in the country (GSS, 2009; Author \& Kendie, 2013). The following excerpts by a 28 year old and a 31 year old respondents respectively, are their verbatim narrations: I live close to the Mfantsepim secondary School, where 1 sleep on a veranda in front of a store. Anytime it rains in the night, 1 become very sad because $l$ have to stand until the rain stops. Even after the rain had stopped, we had to mop the floor before we could put our mats back on the floor to sleep. We encounter this situation whenever it rains in the night. I am more sensitive to mosquitoes and other night insects, so l mount mosquito net every night (28 years, Married, JHS). Currently, I keep my belongings and work equipment in a friend's store and sleep in a kiosk with other 13 shoe-shine boys from the same village (31 years, Single, JHS). 
Some of the respondents also complained of physical stress. This can be associated with walking all day long. These two quotations amply describe the situation: The aspect of my work that is more tedious is the walking; walking from one locality to the other is the problem. Sometimes 1 walk from my place to town (about $3 \mathrm{kms}$ )(38 years, Married, JHS).... cannot be a shoe-shine boy forever. As I grow old walking will become a problem and you know we walk a lot in this job (31 years, Single, JHS).

The qualitative data revealed that the most tedious aspect of the shoe-shine business is walking, which leads to physical stress, and this was also confirmed by the results from the logit model which showed significant relationship between concern about stress and intention to quit the job. Although walking is generally regarded as one of the physical exercises for good health, some shoe-shine operators walk a lot which could affect their health and/or physical appearance, especially walking and working in the scorching sun everyday. The walking involved in the work and its associated physical stress are not suitable for those who are aging and it might be the reason why the older ones would like to quit the business in future. Thus, stress and aging are some of the factors that influence the intentions of some shoe-shine operators to quit the job. The nature of their sleeping places also expose them to thieves and other criminals as reported in this excerpt: We are harassed by thieves at night: they steal our monies and phones. They monitor us and come at night to steal because they know we work during the day and we have money on us (31 years, Single, JHS).

This is a common phenomenon experienced in most cities and urban areas in the country among such informal sector workers who sleep in open places. For instance, the kaya yei in both Kumasi and Accra have also suffered from similar predicaments (Author and Awusabo-Asare, 2007). In a study on economics of shoe shining conducted in Nairobi, Kenya, it was observed that the shoe-shine operators hired a security man who protected them and their equipment in the night from thieves and other criminals (Elken et al., 1982).

Although most of them claimed their incomes are better in the business than prior to migration, for some of them it has been at the expense of their other roles at their places of origin, particularly farming and protection of household members as indicated in these two excerpts: I came from Assin to work in order to save enough money to maintain my oil palm and cocoa farms. I used to send money home for the upkeep of my household and payment of the labourers who work on my farms but now my farms are all bushy because $l$ can no longer afford the high cost of hiring these labourers (26 years, Single, JHS). I think my absence from my place of origin is a contributing factor to my daughter's pregnancy. I think this would not have happened if I were living with them. I would have monitored her and made sure that she goes to bed early at night (38 years, 
Married, JHS). These narratives are typical examples of the negative experiences associated with out-migration from rural areas but the second quotation is rarely mentioned in most discourses on implications of rural-urban migration at the places of origin. For these respondents, a reverse migration from urban to their rural places of origin is quite obvious.

\section{Future Intentions in the Shoe-shine Business}

The last research question focuses on future intentions of the shoe-shine operators in the business. The main motive for engaging in the shoe-shine business is economic. However, given the precarious and tedious nature of the business as reported by some shoe-shiners, some of them had planned to quit the business and among the reasons given were: physical stress, job not being lucrative and stable, to engage in their chosen profession, aging and the neglect of their other responsibilities at their places of origin while others said they would remain in the business because opportunities for alternative jobs were limited. The following excerpts indicate the diverse views expressed:

My intention is to save enough money, stop the shoe-shine business and settle at Assin Fosu and establish a mechanic shop. The reason being that $l$ am also interested in mechanics business and since I have learnt it, $l$ would like to benefit from that too (28 years, Single, JHS).

.... I cannot be a shoe-shine boy forever. As l grow old walking will become a problem and you know we walk a lot in this job (31 years, Single, JHS).

I have said earlier that this is not the job 1 am trained to do, l am a driver and as soon as l get the money for my license, I will quit this job. I know if l get my license l will get a car to drive and that will earn me more income than lam earning now (28 years, Married, JHS).

For now, 1 have no intentions of leaving this business because 1 have no other job. So for now, l will remain in the shoe-shine business (28 years, Married, Primary School).

\section{Conclusions}

This paper examines the concerns and future intentions of migrant shoe-shine boys in the Cape Coast Metropolis. The findings indicate that the shoe-shine boys are mostly JHS graduates who are single, aged between 20-29 years and belong to the Akan ethnic group, the largest ethnic group in Ghana (GSS, 2012). 
The results show that their main concerns ranged from injuries from the work, poor accommodation, job not being lucrative, through physical stress to the neglect of their other responsibilities at their places of origin. There is a statistically significant relationship between concern about job not being lucrative and intentions to quit the shoe-shine business, which implies that some of them intend to quit the job for more lucrative jobs. These factors are consistent with the literature on factors that influence intentions to quit a job (Masroor and Fakir, 2010; Jonathan, Thibeli and Darroux, 2013; Mxenge et al., 2014) and also some empirical findings from the shoe-shine business (Elkan et al., 1982).

Since some of them invest part of their earnings in farming at their places of origin, being absent from their farms due to the shoe-shine business was one of their concerns which also showed significant relationships with the intention to quit the job. This is one unique finding which is missing in the literature on intentions to quit a job. Thus, reverse migration from urban to rural areas among some of the shoe-shine boys is feasible because they had already made some investment in their villages of origin.

However, those who had no investment elsewhere intend to remain in the business because there are no alternative jobs. This means that the shoe-shine business provides employment to people who otherwise would have been unemployed. This finding was also noted in the study conducted in Nairobi by Elkan et al. (1982).

It can be concluded that the shoe-shine business is a stepping stone to more stable and lucrative jobs. Some joined the business just to obtain the needed capital to establish a more lucrative business. Among young migrants, the need for capital to establish their own businesses has been widely documented in the literature (Kwankye et al., 2007; Author and Awusabo-Asare, 2007; Awumbila and ArdayfioSchandorf, 2008; Thorsen, 2009; Author, 2010). The main limitation of the study was that socio-demographic factors were not included in the logit model to determine the extent to which they influence the intentions to quit the shoeshine business. This is because the study focuses on their concerns and how these influence their intentions to remain or quit the job.

\section{Recommendations}

The shoe-shine business provides employment for some young migrants in the Cape Coast Metropolis who otherwise would have been unemployed. The Cape Coast Metropolitan Assembly in collaboration with the National Board for SmallScale Industries should organize some training in basic business management and 
occupational health and safety for the shoe-shine boys to sustain their business and also protect themselves against injuries.

The shoe-shine boys should team up to rent low cost accommodation and also seek the assistance of night security personnel to protect them against thieves as some shoe-shiners do in Nairobi (Elkan et al., 1982). The National Board for Small-Scale Industries (NBSSI) and other relevant organizations should endeavour to train young people who have already created their own jobs in the informal sector such as the shoe-shine boys to enable them sustain their businesses. The need to sustain young people in such businesses to prevent them from relapse into the rising levels of unemployment is long overdue.

\section{References}

Abebe, T. (2007). Changing Livelihoods, Changing Childhoods: Patterns of Children's Work in Rural Southern Ethiopia. Children's Geographies, 5(1-2), pp. 77-93.

Adei, D. and Kunfaa, E. (2007). Occupational Health and Safety Policy in the

Operations of the Wood Processing Industry in Kumasi. Journal of Science and Technology 27 (2), pp. 159-169.

Adongo, C. A., Anuga, S.W. and Dayour, F. (2015). Will they Tell Others to Taste?

International Tourists' Experience of Ghanaian Cuisines. Tourism Management Perspectives, 15, pp. 57-64.

Awumbilla, M. and Arddayfio-Schandorf, E. (2008). Gendered Poverty, Migration and Livelihood Strategies of Female Porters. Norsk Geografisk Tidsskrift-Norwegian Journal of Geography, 62 (3), pp. 171-179.

Böckerman, P. and Ilmakunnas, P. (2007). Job disamenities, Job Satisfaction, Quit Intentions, and Actual Separations: Putting the Pieces Together. A Discussion Paper No. 166 Available at: http://www.hecer.fi Accessed 6 April, 2016.

Cowin, L. (2002). The Self-Concept of Nurses and its Relationship to Job Satisfaction and Retention. Unpublished PhD thesis. The University of Western Sydney, Australia.

Elkan, W., Ryan, T.C. and Mukui, J.T. (1982). The Economics of Shoe Shinning in Nairobi.The Royal African Society, UTC, 247-256 Available at: http://www.jstor. org/stable/721730 Accessed $21^{\text {st }}$ October, 2016. 
Feed Magazine (2015). The Last Shoe-shiner of Hong Kong, Feed Magazine HKBU MA International Journalism Student Stories. Available at: https://mailattachment.googleusercontent Accessed 20 ${ }^{\text {th }}$ February 2018.

Geographic Information System (GIS) and Cartographic Unit, (2016). Map of the Cape Coast Metropolis showing the study sites. University of Cape Coast, Cape Coast.

Ghana Social Marketing Foundation. (2003). Apprentice workers at risk. From Available at: http://www.gsmf.com.gh Accessed 13 November, 2008.

Ghana Statistical Service, (2012). 2010 Population and Housing Census Report, Ghana Statistical Service, Accra, Ghana Statistical Service, Noguchi Memorial Institute for Medical Research (NMIMR), and ORC Macro (2009). Ghana Demographic and Health Survey 2008. Calverton Maryland: GSS, NMIMR, and ORC Macro.

Ghartey, N. K. and Dorkenoo, D.K. (2002). Unionising informal workers in Ghana, Unprotected Labour: What role for unions in the informal economy. Labour Education Paper No. 127. Geneva: I.L.O.

Jonathan, H., Thibeli, M. and Darroux, C. (2013). Impact Investigation of Organizational Commitment on Intention to Leave of Public Secondary School Teachers in Tanzania. Developing Countries, 3(11), pp. 78 - 91

Khotkina, Z. A. (2007). Employment in the Informal Sector. Anthropology \& Archaeology of Eurasia, 45(4), pp. 42-55.

Kwankye, S.o., Anarfi, J.K., Tagoe, A.C. and Castaldo, A. (2007). Coping strategies of independent Child migrants from Northern Ghana to Southern Cities. Development Research Centre on Migration, Globalization and Poverty, Working Paper T-23, Available at: http:// www.migrationdrc.org Accessed $11^{\text {th }}$ April, 2009.

Locke, E.A. (1976). The Nature and Causes of Job Satisfaction, In M.D. Dunnette, (Ed.), Handbook of Industrial and Organizational Psychology (1st ed). Chicago: I Rand McNally.

Masroor, A.M., and Fakir, M. J. (2010). Level of Job Satisfaction and Intent to Leave among Malaysian Nurses. Business Intelligence Journal, 3(1), pp. 124-137.

Matelong, K. N., Sergon, C. D., Tuwei, J. G. and Cheptumo, J. I. (2013). Shoe Shine Entrepreneurs Social Responsibility Practices on Loyalty in Eldoret Town, Kenya, International Journal of Business and Management; 8, pp. 23.

Mxenge, S. V., Dywili, S.M. and Bazana, S. (2014). Job Engagement and Employees'Intention to Quit among Administrative Personnel at the 
University of Fort Hare in South Africa. International Journal of Research in Social Sciences, 4(5), pp. 129-144.

Ongori, H. (2007). A Review of the Literature on Employee Turnover. African Journal of Business Management, June, pp. 49- 54.

Owusu, S.A., Blankson, E.J. and Albert M Abane, A.M. (2011). Sexual and Reproductive Health Education among Dressmakers and Hairdressers in the Assin South District of Ghana, African Journal of Reproductive Health, 15(4), pp. 109-119.

Pallant, J. (2005). SPSS Survival Manual: A Step by Step Guide to Using SPSS for Windows (version 12), New South Wales, Australia: Allen \& Unwin.

Porter, G., Hampshire, K., Abane, A. M., Tanle, A., Esia-Donkoh, K., Amoako Sakyi, R.O., Agblorti, S.K. and Owusu, A.S. (2011). Mobility, education and livelihood trajectories for young people in rural Ghana: a gender perspective. Children's Geographies, 9 (3-4), 395-410 Available at: http://dx.doi.org/10.108o/ 14733285.2011.590705 Accessed $17^{\text {th }}$ June, 2012

Author, A. and Awusabo-Asare, K (2007). The kaya yei Phenomenon in Ghana: Female Migration from the Upper-West Region to Kumasi and Accra. The Oguaa Journal Of Social Sciences (JOSS), University of Cape Coast, 4 (2), pp. 139164 .

Author, A. (2010). Livelihood Status of Migrants from the Northern SavannahZone Resident in the Obuasi and Techiman Municipalities. A Ph.D. Thesis submitted to the Department of Population and Health, University of Cape Coast, Cape Coast, Ghana.

Author, A., Ilechie, A.A. Awusabo-Asare, K., Ovenseri, G.O. and Anderson, M. (2011). Ocular Conditions among Women Involved in Palm Pernel Oil Processing in the Cape Coast Metropolis, Ghana. Society, Biology and Human Affairs. 76(2), pp. 25-40.

Author, A. (2012). Everybody has his/her Luck: Irregular Migration of Young People from Ghana to Libya and Beyond. Journal of Arts and Social Sciences, 1(1), pp. 43-64.

Author, A. and Kendie, S.B. (2013). Sanitation: A Drawback to Achieving the Millennium Development Goals? The Situation in Ghana. Journal of Arts and Social Sciences, 1(2), pp. 125-147.

Thilde Langevang, Katherine V. Gough, Paul W. K. Yankson, George Owusu and Robert Osei (2015). Bounded Entrepreneurial Vitality: The Mixed Embeddedness of Female Entrepreneurship. Economic Geography, 91(4), pp. 449-473. 
Thorsen, D. (2009). Mobile Youth with Little Formal Education: Work Opportunities and Practices, Development Research Centre on Migration, Globalization and Poverty, University of Sussex.

UNFPA, (2011). Sate of African Youth Report. African Union, UNFPA

UNICEF (2000). Children Working on the Streets of Ethiopia, Available at: https:// mail-attachment.googleusercontent Accessed 20 February 2018.

Werbel, J.D., and Bedeian, A.G. 1989. Intended turnover as a function of age and job Performance. Journal of Organizational Behaviour, 10 (3), pp. 275281. 